\title{
Education, Civic Participation and Identity: \\ Continuity and Change in Hong Kong
}

Paul Morris, Chair Professor, Department of Curriculum Studies, The University of Hong Kong

Flora Kan, Assistant Professor, Department of Curriculum Studies, The University of Hong Kong

Esther Morris, Research Assistant, Department of Curriculum Studies, The University of Hong Kong

\section{$\underline{\text { Summary }}$}

This paper firstly identifies the major legacies inherited by the post-colonial government in Hong Kong, with reference to the key features of access, control and curriculum. Subsequently we examine the state's attempts to reconcile the tension between its quest for legitimacy and for stability. Two dimensions of education, namely, the process of educational policy making and the nature of citizenship promoted through the school curriculum, are analysed respectively in terms of the conceptions of civic participation and identity promoted and implemented by the state. In conclusion we point to the shift in the policy making process and the strengthening of policy actions designed to promote the state’s conception of civic identity. (111 words) 


\section{Education, Civic Participation and Identity: \\ Continuity and Change in Hong Kong}

Paul Morris, Chair Professor, Department of Curriculum Studies, The University of Hong Kong

Flora Kan, Assistant Professor, Department of Curriculum Studies, The University of Hong Kong

Esther Morris, Research Assistant, Department of Curriculum Studies, The University of Hong Kong

\section{INTRODUCTION}

The period of transition leading up to Hong Kong's return to Chinese sovereignty has been the subject of extensive analysis. In the educational domain the shifts associated with the impending handover have been interpreted from a range of perspectives and focused on different aspects of the system. Examples include: the focus on school curricula (Morris and Chan, 1997), which is portrayed as an attempt to reduce its depoliticized and decontextualized nature; the analysis of the interaction of the forces of neocolonization, decolonization and recolonization within the tertiary education sector (Law, 1997); the shifting historical processes of colonization, industrialization, bureaucratization, localization and decolonization within which the transition occurred (Sweeting, 1994); the analyses of the debate which the transition generated with regard to the nature of civic identity in Hong Kong (Lee, 1996); and its impact on policies related to the language of instruction (Adamson and Lai, 1997).

In the political domain, Scott (1989) focused on the crisis of legitimacy which the transition created for the British colonial government and more recently (Scott, 1998) has described the post handover government as 'disarticulated', and characterized by a strong separation between the components of the political system. Turner (1995) analyses the impact of political forces on the way Hong Kong's identity and culture have been portrayed by the governments of Hong Kong and China since the 1960s.

This paper focuses on two interlinked features of education, namely the educational policy making process and the conception of citizenship promoted through the school curriculum, 
which have been affected by the state's attempts to both establish its legitimacy and maintain a high degree of stability following the transfer of sovereignty. These are analysed in terms of the form of civic participation they embody and with regard to the role of the state in defining the nature of the community's identity. Heater (1990) distinguishes between the forms of participation by citizens within the educational domain that are associated with five ideological perspectives (See Table I). This provides an appropriate framework for locating shifts in the form of civic participation promoted by the state especially within those areas of the school curriculum which explicitly promote conceptions of citizenship, such as civic education, social studies and history. The framework can also be used to distinguish the nature of participation which operates in the educational policy making process, and has been adapted for this purpose with the addition of the last row in Table I. The concern is therefore with interpreting changes in two discrete areas, (how decisions about education are made and the image of a good citizen) in terms of the perspective on civic participation and identity that is promoted and enacted by the state.

\section{[INSERT TABLE I ABOUT HERE]}

Hong Kong's political system has been variously described as a form of 'bureaucratic hegemony’ and executive led government. In terms of civic participation the prevailing ideology has been predominantly conservative/elitist, with the elite being drawn from the ranks of the civil service and the business community. The political reforms introduced by the last Governor in 1995 were a belated attempt to promote a more democratic political system and a greater degree of citizen participation. Numerous commentators (e.g. Vines, 1998; Scott, 1998) have described recent post handover changes in the political domain in terms of an attempt to recreate or revamp the traditional colonial model.

Substantial caution needs to be taken in linking changes within the educational system to the political transition. Firstly, the handover only occurred in July 1997 and, unlike those states which emerged from the break-up of the Soviet Empire in the 1980s or from the withdrawal of 
the European colonial powers in the post war period, the first government of the Hong Kong SAR has not embarked on a radical course of decolonization in an attempt to excise vestiges of the colonial past. A premium has been placed on maintaining stability and diversity, a goal that was incorporated in the Basic Law, which specified that Hong Kong's economic and social systems would not change for 50 years after 1997. A number of factors have contributed to this scenario: Hong Kong did not emerge as an independent state; decolonization was not the result of an independence movement; the transition began in 1982 when the departure of the British was announced; Hong Kong's return was seen in the PRC as resolving a national humiliation and as a precursor of its relationship with Taiwan; the transfer has been the subject of massive international media scrutiny; and Hong Kong has been a highly successful free market economy.

The combination of these conditions served to heighten local and international concerns about the effects of the reunification on all aspects of Hong Kong society, and created interlinked tensions for the first government of the SAR. The task of establishing itself as the legitimate government was conditioned by the need to maintain an image of continuity and stability; and consequently, the strategy used by other newly independent, ex-colonial states - of liberating their social and political systems of the symbols of colonialism - was not as readily available. These tensions have, as Law (1997) has demonstrated, resulted in the parallel operation of the processes of decolonization, neocolonization and recolonization.

Secondly, the long period of preparation for the transition saw the colonial government introduce a range of reforms, especially within the political and educational arenas, prior to its departure (Morris, 1988; Bray and Lee, 1993), many of which have been interpreted as an exercise in neocolonization (Law, 1997). Consequently the educational policy agenda of the new government has effectively been strongly influenced by that of the departing colonial government. 
Thirdly, and most problematic, is the question of the genesis of educational reforms which may be the result of, or a response to, factors which are relatively independent of political considerations generally and the resumption of sovereignty specifically. Critical considerations currently relevant are the impact of the recent economic recession in Asia, which emerged shortly after the handover and which has resulted in Hong Kong experiencing a major economic recession for the first time since the mid 1960s. This has, as elsewhere, increasingly placed education at the centre of the policy agenda as questions are asked about the system's efficiency/value for money and the suitability of schooling in preparing pupils for the labour market. Other reforms would seem to have their roots in more global trends designed to address some of the perennial dilemmas faced by education systems, such as the effects and validity of existing systems of assessment, and the optimal method for allocating pupils to schools.

\section{THE LEGACY}

There is no clear divide between the contemporary and the historical. Long established patterns of schooling, reforms initiated by the departing colonial government, and society’s expectations of public schooling, have provided the context within which the first government of the SAR operates. That context is especially important given that the new government's quest to establish its legitimacy and develop a distinctive identity was influenced and constrained by the following needs: to assuage the concerns of the local populace; to demonstrate to the international community China's capacity to allow a capitalist economy to operate in the ways spelt out in the Basic Law and the Joint Declaration; to establish or maintain systems which minimised the potential of subversion. The key features of the educational landscape inherited by the first government of the SAR are summarised below with reference to three features: access, control, and the curriculum.

\section{- Access:}


The historical pattern was of minimal provision by the state along with the encouragement of a large private sector and a structure of provision that was highly elitist and selective (Sweeting and Morris, 1993). Slowly, and primarily in response to various economic and political crises and social demand for schooling, the state began to control, finance and expand the provision of each successive level of school education. Thus, in the 1960s, primary schooling was expanded in response both to demand and to allow young mothers to join the industrial workforce. Subsequently the demand for greater access shifted to secondary schooling and, along with the need to avoid the charge of exploiting child labour, the associated threat of economic sanctions and to create a stronger sense of civic identity amongst Hong Kong's predominantly young population, nine years of free and compulsory education became policy in 1969 and was achieved by 1979. The expansion of access was achieved, not by direct state provision, but through a system of phasing out private, profit making schools and expanding the aided sector. This allowed churches, benevolent associations and commercial organisations to run schools primarily using public funds. In the 1970s tertiary education's growth was limited by the Government on the grounds that social conflict might arise from the existence of overeducated unemployed people. In the late 1980s an expansion programme was initiated and this was rapidly accelerated in 1989 in response to the crisis of confidence which hit Hong Kong following the suppression of students in Tienanmen Square (Morris, McClelland and Leung, 1994).

The main legacy of this pattern for the new government has been to (a) limit its capacity to expand access to education as a key element of its policy agenda, and (b) to commit it to allocating an increasing level of public expenditure to education. This is proving critical in the current economic climate, which has seen economic growth and government revenues decline rapidly.

\section{- Control:}


The post-war period saw the colonial government give itself extensive powers to decide the content of syllabuses, textbooks and examinations. The primary motive for this was to ensure that schools did not promote ideologies which were subversive of the state (Morris and Sweeting, 1993). The result was the effective depoliticization and decontextualization of the curriculum (Morris and Chan, 1997) to ensure that pupils focused on remote/abstract knowledge and avoided the study of the local context or 'sensitive' topics.

The expansion of public schooling in the 1950s and 60s was largely achieved through the work of missionary groups who fled the civil war in China and were encouraged by the government to schools in Hong Kong. These groups, whilst not hostile to the colonial government, desired to teach their religious beliefs and to select whom they taught. This placed limits on how the government exercised its power. The outcome was a compromise in which the state controlled the content of school subjects, the textbooks used and the nature of the public assessment. Schools were allowed to decide which subjects were selected, the time devoted to them, the nature of the informal and spiritual curriculum, and the selection of pupils. With the advent of mass secondary education in 1979 the power of schools to select pupils was reduced with the introduction of a centralised allocation scheme.

Educational qualifications served as the primary source of access to the rapidly growing modern sector of the economy from the mid-1960s and success in public examinations and an emphasis on certification have emerged as the primary goals of schooling. The result is the emergence of a market in which secondary schools compete to maximise and improve their intake of academically more able pupils. This market has served as a powerful source of indirect control and influence on school-based decisions, especially with regard to the nature of the curriculum (Morris, 1997).

The legacy inherited by the new government is thus one in which: schools have exercised a great deal of autonomy as long as they avoided any inputs which might be viewed as subversive; 
a pattern of decentralisation has prevailed; and a context in which selection and competition serve as powerful influences on schools’ priorities.

\section{- Curriculum:}

After the Second World War, the emphasis was on providing pupils with access to the basic disciplines of learning as represented by traditional academic subjects. The subject-dominated curriculum was strongest at the secondary level, but at primary level it was also organised around three subjects: English, Chinese and mathematics. The academic and abstract orientation of the curriculum was reinforced by the colonial government's desire to ensure pupils were not exposed to material that might be viewed as sensitive or controversial. [Vocationally oriented curricula were officially promoted in the very small technical school sector but in practice their low status resulted in a tendency to focus on the key academic subjects.] The strong links between subject based certification, access to higher levels of education and employment ensured that the subject based curriculum was also the most effective route to well paid employment (Foster, 1965).

In the past two decades, the government has promoted a range of reforms designed to reduce the boundaries between school subjects, between teachers and pupils and between the various components of school curricula (especially goals and assessment). Examples include the Activity Approach, the Target Oriented Curriculum, the creation of integrated subjects (integrated science, social studies, liberal studies and general studies), the promotion of cross curricular themes (civic, moral, sex and environmental education) and of School Based assessment systems.

On the eve of the handover there was a flurry of procedural adjustments as the colonial government co-operated with the PRC to ensure a smooth transition. School textbook publishers were provided with 'guidelines' advising them to observe the 'one China' policy; the Curriculum Development Council recommended the strengthening of the 'Chinese elements' in existing curricula; and in 1996 it was decided that from 1998 Putonghua would be taught in all primary 
schools and that civics would be made available as an optional subject in Secondary 1 to Secondary 3. (Previously it was only promoted as a theme designed to permeate all subjects.)

The curriculum inherited by the post-1997 government is thus characterised by its strong academic orientation; its resistance to reform; a strong degree of school choice in determining the nature of what pupils study; and the promotion of more Chinese elements in the form of the introduction of Putonghua and civic education as school subjects.

\section{POST 1997 (1) POLICYMAKING PROCESSES}

The transition period was characterised by hyper-activity in the area of educational reform. From 1984 to 1997 the Education Commission produced a total of seven reports which recommended wide ranging changes to many aspects of education (Morris, 1997).

The first government of the SAR outlined its plans for education on 1 July 1997. The major goals identified were:

- $\quad$ the pursuit of quality education

- $\quad$ the creation of a committed teaching profession

- to develop pupils who can write English and Chinese and speak Cantonese, Putonghua and English

- $\quad$ to promote whole day schooling

- $\quad$ to promote the use of IT

- to promote the teaching of Chinese culture and heritage, and to strengthen civic education

A notable feature of the SAR government's educational reform agenda is the extent to which it accelerates many of the directions identified prior to the handover. For example, the move from bisessional to whole-day primary schooling was proposed by Education Commission Report No. 4 (ECR4, 1990); the promotion of mother-tongue instruction had long been recommended by the government and was endorsed in ECR4; and the pursuit of an all graduate teaching profession was central to Education Commission Report No. 5 (ECR5, 1992) but it 
limited itself to recommending that in the short term only 35 per cent of primary school teachers be employed as graduates.

The novel elements in the new government's policy agenda were the promotion of Information Technology (IT) and of Putonghua. Both of these had been the subject of policies by the colonial government but they were low key and low cost affairs which did not have a major impact on schools. The promotion of IT and Putonghua are now central themes of public policy addresses and they are receiving substantial financial support. In the next section we examine how the last of the listed goals has been pursued.

However, whilst the previous government actively promoted educational reform this was often more a symbolic act in response to various crises than one designed to change the realities of schooling (Sweeting and Morris, 1993; Morris and Chan, 1997). The handover has seen a greater willingness by the state to try to enhance the quality of schooling generally and ensure the implementation of policies in schools. This is best illustrated by the medium of instruction issue. The use of the mother tongue had been government policy since the late 1970s but schools were, in the final analysis, allowed to decide which language to use. Consequently the vast majority continued to use English as this attracted the more able pupils and maximised their opportunities for access to tertiary education. The SAR government has moved to implement the policy and from 1998 all secondary schools, except 114 who had demonstrated their capacity to provide English Medium Instruction, were required to use Chinese as the medium of instruction.

In terms of the policy making process, as noted earlier, the colonial government pursued a policy of decentralisation especially of implementation tasks and developed an extensive network of advisory bodies. The primary responsibility for all areas of public policy was vested in the civil service who usually decided the members of governmental advisory bodies. Thus whilst non-official (i.e. non-civil servants) and appointed members of the Executive Council (EXCO) could, in part, critique and advise on government policy, the final decision and its 
implementation remained in the hands of the civil service. Despite this executive led, or bureaucratic, control of the political system the state, compared to some of its East Asian counterparts, was neither strongly interventionist nor did it operate on the basis of long term strategic planning. The instinct of the government, which was committed to a policy of laissezfaire and possessed a low level of political legitimacy, was to avoid change and conflict if things worked. When changes were considered the process of policy making was lengthy and involved extensive consultation. Policy making in the area of education was reactive rather than proactive and tended to involve a response to crises rather than an exercise in long term planning (Sweeting and Morris, 1993). Policies would not be pursued, or take on an advisory status, where they might face opposition or be in conflict with existing practices. Thus schools were often left with the unenviable task of having to decide how to reconcile unresolved conflicts, such as which medium of instruction to use and how much time to devote to different subjects. When conflicts did arise this was usually dealt with by the use of third party interventions (Cheng, 1997). The result of the combination of these conditions was that educational policy can be characterized as bureaucratic led inertia punctuated by crisis management in response to any threats to the legitimacy of the state (Sweeting and Morris, 1993).

The instincts of the Chief Executive, Tung Chee Hwa, seem equally patrician but more interventionist, designed to establish strong and decisive government; and within the immediate post handover period, seeking to curtail the power of the bureaucracy. This is reflected in the adjustments that have occurred in the process of policy making in the educational domain. First, to speed up the process of policy making, demonstrate strong leadership and bypass the cautious and conservative style of the civil service, the Chief Executive gave appointed members of EXCO the Executive Council responsibility for broad areas of public policy, and he personally established various task groups to directly advise him on specific areas of public policy. Examples include the Commissions for Strategic Development, Innovation and Technology, the 
Elderly, and the Advisory Committee of international business people. Thus there has been the emergence of a group of non-civil servants who have responsibility for developing and advising on policy, and who are seen to have direct access to and have been chosen directly by the Chief Executive. In effect a quasi-ministerial system began to emerge which creates the potential for a new centre of power to develop within the policy making community. Civil servants continue to promote and defend government policies in the Legislative Council, which primarily consists of elected members. The outcome has been that the fairly clear hierarchy of decision making and the distinction between making policy and advising on it has become blurred. Tension has surfaced as senior civil servants, those individuals directly appointed by the Chief Executive, and the various advisory committees, compete to define and protect their territorial boundaries.

An element of indecision has also inevitably emerged as the new task groups, established advisory bodies and the civil service all compete to define the nature of the government's policy priorities. Thus, in the case of the implementation of the language of instruction, the government's policy was clearly to require the majority of schools to shift to using Cantonese. This policy was unpopular with many parents and schools and the government was under substantial pressure to reconsider. This was exacerbated when a senior adviser on education to the Chief Executive expressed the view that the policy would have to be reviewed in the following year. This made implementation more difficult and raised questions as to the precise nature of long term policy and who decided it. Similarly the government's commitment to the Target Oriented Curriculum initiative was also thrown into question as the civil service continue to promote it whilst members of the new policy making community either ignore its existence or argue for its abandonment.

Secondly, the time lag between policy formulation and implementation has been truncated and this has been partly achieved by reducing the extent of consultation. This would seem to reflect the government's attempt to provide strong and decisive leadership and an assertion of its 
own legitimacy to govern. The consequence has been the introduction and attempted implementation of policies that have been underdeveloped and a cause of substantial conflict. Examples include: the stipulation that school principals had to retire at 60 years of age; that degrees granted in Commonwealth countries and held by teachers would no longer be automatically recognised; and the implementation of a policy which required all but 100 secondary schools to use Chinese as the medium of instruction. The first two of these policies were effectively deferred and subsequently clarified. The policy on medium of instruction was implemented, but 14 schools successfully appealed and were allowed to continue to use English.

The same pattern of reduced consultation and the truncation of the policy making process is evident in two recent curriculum development exercises. These reforms have involved the creation of civic education as a new subject (Curriculum Development Council [CDC] 1998) and a revision of the Chinese history syllabus (CDC, 1997). The nature of these changes are discussed in the next section, but in terms of process it took less than two years to draft and implement the new syllabus for Chinese history and about two months to develop the syllabus for civic education. In comparison the Civic Education Guidelines, which appeared in 1996, took over two years to complete, and the previous revision of Chinese history took more than five years. With regard to the QEF, there was only four months between its announcement and the allocation of the first batch of funds. Consequently a variety of issues have emerged (e.g. the criteria for selection and means of evaluation) which have served to query the value of the exercise.

The government also considered radically reducing the number of advisory committees in the area of education on the grounds that they slowed down and hampered policy making and implementation. The consultancy report (Education and Manpower Bureau, 1998) commissioned to study the problem finally recommended the disestablishment of some inactive committees, but did not propose any fundamental changes to the status quo. The original line of action was not 
pursued as it was recognised by the group who considered this issue that the advisory mechanism and the process of consultation improved the government's legitimacy, allowed wide consultation, and the incorporation of dissident voices.

An associated adjustment in the policymaking arena has involved the persons appointed to the plethora of advisory bodies in the area of education (Morris, 1997). This shift broadly reflects the criteria employed by the PRC to select members of the various educational advisory and consultative bodies that were established during the transition period. The colonial government recruited a mixture of senior members of the main missionary bodies (the Anglicans and Catholics), senior industrialists and manufacturers and academics onto its advisory bodies. The overall pattern has continued but increasingly those selected to sit on advisory bodies are persons predominantly drawn from the ranks of the business community. Whilst some of these have been longstanding supporters of the PRC many also served as senior advisers to the colonial government. Reforms which are now being discussed within that community continue to focus on the need to promote more 'Chinese elements'; for example, the restructuring of the school system to create a $6+3+3$ model to follow what is variously described as a world trend and the predominant structure operating in China. Consideration is also being given to making Chinese history, Putonghua and civics education compulsory school subjects. An earlier attempt to make Putonghua a compulsory subject was deferred as schools complained firstly that they would not be able to recruit a sufficient number of trained teachers, and secondly about the impact of such a policy on an already crowded timetable. Overall, the reemergence of a coalition between the government and the business community, the creation of a quasi ministerial system drawn from outside the ranks of the civil service or legislature, the more direct coupling of policy and its implementation, and the curtailing of the advisory/consultation process suggest that the process of policy making is returning to a more elitist orientation. It also supports Scott's (1998) 
contention that the political system is becoming 'disarticulated' as the various components of government are increasingly insulated and their relationships fractious.

\section{POST 1997 (2) THE CURRICULUM: CULTURE AND IDENTITY}

Depictions of the social psychology of Hong Kong people, and its implications for the nature of identity have tended in the 60s and 70s to portray a society which is apolitical, atomistic, materialistic, paternalistic, and family rather than community oriented (King, 1977; Lau, 1981). In his classic paper, Turner (1995) argues that both the government of China and the colonial government sought to maintain that image despite the growing evidence of the emergence in the 1980s of an autochthonous culture and a distinctive local identity. Hong Kong people have been portrayed in official documents as 'subjects', 'compatriots', 'residents', and were at best conceded a distinctive 'lifestyle' and a 'materialistic/capitalist way of life'. He explains the motives for this:

Given the vehemence of its objections to democratic development. China cannot be expected to approve representations of the Hong Kong people that show a cohesive cultural identity, particularly an identity constituted against the Mainland.

And:

For quite different reasons Britain has also avoided any policy emphasizing the separateness of local culture. This has less to do with acceding to China's wishes than with justifying its decision to dispose of 3.25 million British passport holders.

Whilst previously the British and Chinese government sought to deny the existence of a local culture and identity, the post-handover period has seen the state playing a more active role in creating a unified national identity. Such a role had been advocated for some time. For example, the Preliminary Working Committee for the SAR opined in 1995 that: 
Civic education in Hong Kong has been underemphasized, and is weak in nationalism and patriotism... following the resumption of Chinese sovereignty, civic education in Hong Kong should aim at building nationalism and patriotism, and at strengthening the teaching of the Basic Law and the concept of "one country, two systems”.

Adjustments designed to achieve the goals of enhancing knowledge of and pride in Chinese history and culture were also made to the curriculum prior to 1997 (Morris, 1988). Since the handover intentions have been reflected in policy actions and the main public proponent of this has been the Chief Executive. His public speeches have stressed his vision of the role of education in developing citizenship and identity. The following extracts are illustrative:

Every society has to have its own values to provide a common purpose and a sense of unity. Most of the people of Hong Kong are Chinese, some are not. For a long time, Hong Kong has embraced the eastern and western cultures. We will continue to encourage diversity in our society, but we must also reaffirm and respect the fine traditional Chinese values, including filial piety, love for the family, modesty and integrity, and the desire for continuous improvement. We value plurality, but discourage open confrontation; we strive for liberty but not at the expense of the rule of law; we respect minority views but also shoulder collective responsibilities. I hope these values will provide the foundation for unity in our society.

(Speech at the ceremony to celebrate the establishment of the HKSAR on 1 July 1997).

The young people of Hong Kong are very fortunate. Whenever they are asked about responsibilities towards the country and people, some tend to be at a loss and sometimes self-contradicting. Such characteristic can be attributed to the unusual historical situation of Hong Kong.

It is precisely because adolescence is the most innovative period in one's lifetime that I consider that fulfilment of obligations and acceptance of responsibilities, in this context, should be more important than pursuit of their rights. This does not simply concern the right way to enhance self-accomplishment, develop one's potentials, and make one's dream come true. More importantly, it is to create an atmosphere and promote an attitude of correctness and vitality in the local community, thereby resolving satisfactorily the unhealthy problems prevailing in Hong Kong and among the youth. I firmly believe that it is the expectation of Hong Kong people that our young people will demonstrate such a spirit, that is, to focus more on the fulfilment of obligations and be more committed to oneself and the community.

(Speech at the Conference on the Review of the Implementation of the Charter for Youth, December 20, 1997.) 
...we must step up civic education so that our youngsters will have a better understanding of China, the Chinese culture and history, the concept of "one country, two systems' and the Basic Law. Through better understanding, we hope to inculcate in them the passion, and the concern for China, the pride of being Chinese, and a constant readiness to contribute towards the well-being of not just Hong Kong but the entire country.

(Speech at the Gala Banquet of the International Forum of Leaders in Higher Education, July 4, 1998)

The recurring themes are: the promotion of traditional Chinese values, the avoidance of confrontation, a focus on the obligations and responsibilities of individuals towards the country and community, moral 'correctness', and a stress on societal values. Chinese culture and values are portrayed in a way that suggests that they are a homogeneous and monolithic entity and they are associated with a desirable range of values (sense of unity, consensuality, modesty, integrity etc.). Conversely, western culture is associated with the less desirable features of individualism and economic development (e.g. materialism and social conflict). The focus is, therefore, on strengthening the promotion of social order, a homogenised set of values and emphasising the role of the individual as part of the community. The depiction of Chinese culture and values as a totalizing and homogenized entity suggests that there is not a distinctive Hong Kong cultural identity or that if there is its inclusion in public discourse is discouraged. The goal according to Siu (1996) is to create unquestioning political commitment through the promotion of an intensely unifying 'cultural identity' which, she argues, is differentiated from people’s day to day 'cultural experiences'. In parallel the portrayal of Chinese values as a set of virtues suggests that those features of Hong Kong's social psychology which are problematic are derived from the influence of the west.

The themes stressed by the Chief Executive have been most obviously incorporated in the curriculum through three vehicles. As noted earlier, the Education Department produced a syllabus for the new subject 'civic education', and revised the Chinese history curriculum. The syllabus for civic education created a separate school subject at junior secondary level, whereas previously 'civics' existed as a cross-curricular theme. This syllabus is strongly linked to and derived from the 
guidelines produced in 1996 (ED/CDC, 1996). It recommends that the subject be taught over at least two consecutive periods per week, and encourages teachers to select the content according to the local situation. Ultimately though, under the principle of school-based curriculum development, “...schools may decide whether to implement this Syllabus as an independent/integrated subject or to integrate it into other subjects” (CDC, 1998, p.4).

The curriculum is organised around six areas, namely: family; neighbouring community; regional community; national community; international community; and, citizenship and civil society. In the first five sections, the emphasis is on the pupil's moral obligations and duties to the family and the community. A more critical perspective and a concern for individual rights is reserved for the final area of study - citizenship and civil society - which contains a separate topic entitled ‘critical thinking’.

The subject avoids any direct attempt to promote the political ideology of the Chinese Communist Party; instead pupils are expected to understand the basic law, the constitution of China, and aspects of its economy and geography. Along with the emphasis on the duties and responsibilities of a citizen, which echoes the approach of the colonial government towards civic education, there is a limited attempt to develop pupils' affinity to Chinese culture and values. One of the subject's four objectives in the knowledge domain is to help students to understand 'the special features of Chinese culture and the structure of the Chinese government.' (CDC 1998, p.2) Examples of the associated 'guiding questions' and 'reflections' around which the syllabus is organised include:

'To what extent do I understand the traditional Chinese family values?' 'Do I possess any of them?' 'What traditional family values do Chinese people hold?' 'Do I possess any of them?' 'What are the meanings of these values to families nowadays?' (CDC, 1998, p.11)

'What feelings do I have towards the rivers and lands of our country?' (CDC, 1998, p.16)

'Am I proud of being Chinese?' 'What will I do to promote my sense of pride of being a Chinese?'(CDC, 1998, p.16)

'What are the major thoughts and beliefs of the Chinese?'(CDC, 1998, p.17)

'What creations and inventions of China impact on the world?' (CDC, 1998, p.17) 
'What attitudes should I have in the ceremony of raising the national flag and playing the national anthem?'(CDC, 1998, p.27).

The intention of presenting the subjects content as a series of questions to be addressed in the classroom is designed to promote discussion and critical thinking. The corollary is that the document avoids any clear statement as to the possible or expected answers. This is a major departure from other curricula documents, which tend to provide detailed information on the content of what should be taught. The individual teacher of 'civics' is thus left with the unenviable task of trying to define the nature of Chinese values, thoughts and beliefs. The teachers' task has probably not been facilitated by their own exposure in school to Chinese culture through Chinese history and Chinese language/literature. According to Luk (1991) local pupils learnt from these subjects to identify themselves as Chinese but not how to relate that 'Chineseness' to either contemporary China or the local Hong Kong landscape. It was a Chinese identity in the abstract, a patriotism of the émigré probably held all the more absolutely because it was not connected to tangible reality. Further, the promotion of issues-based teaching and critical thinking is premised on the value of recognising alternative perspectives and non-categorical knowledge. But the new syllabus fails to identify any issues within its guiding questions and there is a tendency to suggest that there is a homogeneous and taken for granted understanding of the nature of Chinese values and culture.

Chinese history exists as a subject alongside ‘world' or ‘international’ history in Hong Kong's schools. In the past, to avoid it being used as a vehicle for promoting Chinese nationalism and destabilising the government, it focused on periods of ancient history. For instance, the scope of study was only extended to the periods 1911, 1945, and 1949, in the 1965, 1972, and 1979 Certificate of Education Examinations (CEE) respectively. In the 1995 CEE revision, the scope was extended to 1976 only, thus excluding the 1989 June Fourth Incident. This arrangement might be attributed to political sensitivity, which meant that the British colonial government did not want the already tense relationship with China to deteriorate further. Recent amendments to the formal 
curriculum have added 'cultivating a sense of belonging to our country' as one of the subject's overall aims. The objectives have also been amended and elaborated to include: 'To enhance pupils' sense of belonging and affection to the Chinese race through learning Chinese culture', and '.. to understand that Chinese culture has the characteristics of being able to integrate with different cultures and transform into a new form of Chinese culture.' (p.8). Other changes include recommending that teachers make reference to the history of Hong Kong in their teaching and encouraging the transmission of a rigid set of civic and moral values through the subject. For example, illustrations are made concerning emulating/condemning the good/bad behaviour of certain historical personalities with reference to what they did. Emphasis is put on transmitting what is the correct/incorrect value rather than on examining those values.

Recently the Education Commission (1999) published a consultation document designed to create a new set of aims for education. Its major departure from the previous such exercise (EMB, 1993) is its attempts to consolidate the central role of schools in promoting a sense of national identity and in so doing it identifies the areas in which Hong Kong is viewed as 'unique'. It explains:

Of social significance is the fact that reunification with the motherland confirms the Chinese national identity of the Hong Kong people. Under the principles of "One country, Two systems" and "Hong Kong people ruling Hong Kong”, our young people need to understand more about the culture, as well as the present and future developments of our motherland. They also need to appreciate the unique geographical and political characteristics of Hong Kong to the full. (p.10)

This is followed by an attempt to explore the issues that should be taken into account in implementing the aims. Unfortunately the critical issues - such as the divisive system of selection at primary six that places pupils in one of five bands of ability, which determines their secondary school allocation - are avoided. Instead the document presents a series of questions about perspectives on schooling for all the stakeholders involved that amount to mere truisms. For example:

Should the government provide adequate information to parents? 
Should schools uphold the basic principle of education?

Should teachers be aware that students play the main role in the learning process?

Should parents strengthen their communication and co-operation with schools? (pp.25-26)

The clearest denial of any sense of local self identity beyond a recognition of the existence of a distinctive life style is contained in the images used for the publicity of the EC document. This portrayed pupils as four cartoon ducklings wearing school ties, bags, jewellery and makeup.

The perspective outlined by Tung Chee Hwa, and promoted in civic education, Chinese history and the proposed "Aims of Education", is consonant with the role that civic education is increasingly playing in many East Asian societies. For example, Ichilov (1994) noted that:

While in the west civic education emphasises instruction in the values guiding the relation of individuals to the state and polity, in much of Asia... the stress is on interpersonal or moral values... Asian countries rely on education to teach a code of behaviour for everyday life along with loyalty to the state.

However, in the case of Hong Kong, the loyalty being promoted is not to the state per se, but to a sense of national identity based upon a homogeneous and totalizing sense of Chinese culture, morality and values. Similarly, Meyer (1988) argued that from 1979 the PRC moved away from emphasising equality and redistribution towards the promotion of more hierarchical values, which stress correct attitudes and moral obligations. This focus on morality is also echoed in the policies strongly advocated by the political leaders of Singapore (Koh, 1998) and Malaysia since the early 1990s, who have stressed the primacy of Asian and Confucian values. It also has its equivalence in the educational policies of the new right in the USA and UK in the 1980s, which stressed traditional and family values, the primacy of national identity and a return to 'basics'. Thus, for example, the role of history in the UK national curriculum has been portrayed (Goodson, 1994) as being designed to inculcate a sense of national identity and a reassertion of the state in nation building.

Porter (1991) distinguishes between three types of citizenship education -- citizenship as 'status' (the relationship between the individual and the state); as 'volition' (embracing feelings of 
togetherness, community, culture, and history); and as 'competence' (an active, involved participation in debate and decision making). In these terms the curriculum prior to 1997 stressed the 'status' aspects of citizenship. The introduction of civic education as a school subject and the changes to the Chinese history curriculum involves strengthening citizenship as a form of 'volition' - specifically a sense of belonging to Chinese culture and values. Citizenship as a form of 'competence' continues to be neglected. In terms of Heater's distinction between the forms of political participation held by five doctrinal positions, what emerges is that the curriculum reforms emerging in Hong Kong are increasingly promoting a nationalist/integrative doctrine which attempts to deny the existence of a local culture or lifestyle beyond that of its lifestyle. There are also remnants of what Heater terms a conservative/elitist doctrine with its emphasis on the loyalty of the masses and of the right of the elite to govern.

Whilst these changes in the school curriculum have been used to illustrate some of the effects of the transition, they also illustrate a pattern of continuity. The syllabus for civic education as a separate subject was largely derived from the Guidelines on Civic Education produced in 1996, which replaced the first set of guidelines produced in 1985. Each of these represented a more politicised and less descriptive view of the role of civic education in schools. Similarly, the certificate level Chinese history curriculum was amended in 1995 to allow pupils to study the history of China up until 1976 and the 1998 revision of the junior secondary syllabus was based on the 1982 syllabus. The attempts to deny the existence of a local culture or identity were central to the policies of the governments (of China and Hong Kong) long before the handover.

For the present the continuing image of the good citizen being advocated by the state is one that emphasises the duties and obligations of the individual to society. The novel and emerging dimensions are the strengthening of the promotion of moral behaviour, which is associated with traditional Chinese values, and loyalty to 'the' Chinese culture. However, the precise nature of those 
values, obligations and duties in civic education remain unspecified and for individual teachers to define.

\section{CONCLUSION}

The government's desire to develop a distinctive identity by pursuing a decolonizing reform agenda has been constrained by the need to promote an image of stability and continuity, and by the legacies inherited from the period of British colonialism. Consequently, the return to the sovereignty of the PRC on 1 July 1997 has not involved radical changes but has seen a shift in the policy making process and the strengthening of policy actions designed to promote the state's conception of civic identity. The policy making process has seen the emergence of a new centre of power within the policy making community as the Chief Executive has directly appointed individuals and groups, primarily drawn from Hong Kong's business elite, to achieve a firmer and more decisive style of governance. This has challenged the traditionally powerful role of the civil service in the process of policy making. It has also brought with it the creation of new boundaries and tensions as the new members of the policy-making community compete with the traditional centres of power to define their territories. The outcome bears many of the features of the process of disarticulation in the political domain that Scott (1998) identified. In terms of civic identity, the handover has seen a shift from the state denying the existence of a local culture and identity towards its more actively promoting a totalizing conception of self-identity based up on a national cultural and moral agenda.

The shift in the policy-making process and the strengthening of policy actions were interpreted in terms of the nature of civic participation that they embody. The policy making process in the educational arena was portrayed as elitist and represented a return to the more traditional colonial pattern. In terms of the view of civic participation explicitly promoted through school subjects, the emerging pattern is one that stresses a nationalist/integrative, cultural and moral agenda that involves the denial of the existence of an autochthonous culture 
and identity. The overall outcome is one in which the state is promoting a view of civic participation which envisages political power remaining in the hands of an elite and the active promotion through schools of a cultural and moral agenda which stresses homogeneity, harmony, responsibility and social cohesion. This combination seems designed to allow the government to distinguish itself from its predecessor by establishing its legitimacy as the promoter of Chinese values and moral behaviour. In so doing it avoids the charge of pursuing radical decolonizing policies or of promoting ideological indoctrination, but at the same time ensures that it promotes its own distinctive vision of citizenship, identity and of public participation specifically. 


\section{References}

Adamson, B. \& Lai, W. A. (1997) Language and the curriculum in Hong Kong: dilemmas of triglossia, in: Bray, M. \& Lee, W. O. (Eds) Education and Political Transition: Implications of Hong Kong's Change of Sovereignty (Hong Kong, Comparative Education Research Centre, The University of Hong Kong).

Bray, M. \& Lee, W. O. (1993) Education, democracy and colonial transition: The case of Hong Kong, International Review of Education, 39(6), pp. 541-566.

Cheng, K. M. (1997) The policymaking process, in: G. Postiglione \& W.O. Lee (Eds) Schooling in Hong Kong: Organization, Teaching and Social Context (Hong Kong, Hong Kong University Press).

Clark, J., Scarino, A. \& Brownell, J. (1994) Improving the Quality of Learning (Hong Kong, Hong Kong Bank Language Development Fund/Institute of Language in Education).

Curriculum Development Council (1997) Chinese History Syllabus (Forms I-III) (Hong Kong, Education Department).

Curriculum Development Council (1998) Syllabuses for Secondary School: Civic Education. (Hong Kong, Education Department).

Education Commission (1999) Education Blueprint for the $21^{\text {st }}$ Century: Review of Academic System Aims of Education. Consultation Document (Hong Kong, Government Printer).

ECR 4 (1990) The Curriculum \& Behavioural Problems in Schools (Hong Kong, Government Printer).

ECR 5 (1992) The Teaching Profession (Hong Kong, Government Printer).

ECR 7 (1997) Quality School Education (Hong Kong, Government Printer).

ED/CDC (1996) Guidelines on Civic Education in Schools (Hong Kong: Education Department.

Education \& Manpower Branch (1993) School Education in Hong Kong: a Statement of Aims. (Hong Kong, Government Printer).

Education \& Manpower Bureau (1998) Consultation Document on the Review of the Educationrelated Executive and Advisory Bodies. (Hong Kong, Government Printer).

Foster, P. (1965) Education \& Social Change in Ghana (London: Routledge \& Kegan Paul).

Goodson, I. F. (1994) Studying Curriculum (Buckingham, Open University Press).

Heater, D. (1990) Citizenship: The Civic Ideal in World History, Politics \& Education (London, Longman). 
Ichilov, I. (1994) Political education, in: T. Husen, \& T. N. Postlethwaite (Eds) The International Encyclopaedia of Education. $2^{\text {nd }}$ edition (Oxford, Pergamon).

King, A. S. Y. (1977) The political culture of Kwun Tong: A Chinese community in Hong Kong. Southeast Asian Journal of Social Science, 59, pp. 1-2.

Koh, T. B. (1998) The Quest for World Order: Perspectives of a Pragmatic Idealist (Singapore Institute of Policy Studies: Times Academic Press).

Lau, S. K. (1981) Utiliarianistic familism: the basis of political stability, in: A. Y. C. King, \& R. P. L. Lee (Eds) Social Life and Development in Hong Kong (Hong Kong, Chinese University Press).

Law, W. W. (1997) The accommodation and resistance to the decolonization, neo colonization and recolonization of higher education in Hong Kong. Comparative Education, 33 (2)

Lee, W.O. (1996) From depolitization to politization: the reform of civic education in Hong Kong in political transition, in, Chinese Comparative Education Society - Taipei (Eds) Education Reform: From Tradition to Postmodernity (Taipei, Shih Ta Publishing Co.).

Luk, H.K. (1991) Chinese culture in the Hong Kong curriculum: heritage and colonialism, Comparative Education Review, 35, pp.650-658.

Meyer, J. (1988) A subtle and silent transformation: moral education in Taiwan and the PRC, in: W. Cummings, S. Gopinathan \& Y. Tomoda (Eds) The Revival of Values Education in Asia \& the West (Oxford, Pergamon).

Morris, P. (1988) The effect on the school curriculum of Hong Kong's return to Chinese sovereignty in 1997, Journal of Curriculum Studies, 20 (6), pp.509-520.

Morris, P. (1997) School knowledge, the state and the market: an analysis of the Hong Kong secondary school curriculum, Curriculum Studies,.29(3), pp.329-349.

Morris, P. \& Chan, K.K. (1997) The Hong Kong school curriculum \& the political transition: politicisation, contextualisation \& symbolic action, in: M. Bray \& W. O. Lee (Eds) Education \& Political Transition: Implications of Hong Kong's Change of Sovereignty. (Hong Kong, Comparative Education Research Centre, The University of Hong Kong).

Morris, P., McClelland, J.A.G. \& Leung, Y.M. (1994) Higher education in Hong Kong: the context of and rationale for rapid expansion, Higher Education, 27, pp. 125-140.

Morris, P. \& Sweeting, A. (1991) Educational \& Politics: the Case of Hong Kong from an historical perspective, Oxford Review of Education, 17 (3), pp. 249-267.

Oliver, D. \& Heater, D. (1994) The Foundations of Citizenship (Oxford, Wheatsheaf).

Pachocinski, R. (1993) Current curriculum changes in Poland: a national report, Curriculum Studies. 1, pp. 215-232. 
Porter, A. (1991) Political literacy, in: D. Heater \& J. A. Gillespie (Eds) Political Education in Flux (London, Sage).

Scott, I. (1989) Political Change \& the Crisis of Legitimacy in Hong Kong (Hong Kong, Oxford University Press).

Scott, I. (1998) Hong Kong's post-handover political system: disarticulation and the reemergence of bureaucratic hegemony, Seminar Paper Delivered at the Australian National University, 20 November 1998.

Siu, H. (1996) Remade in Hong Kong: weaving into the Chinese cultural tapestry, in: T.T. Liu and D. Faure (Eds) Unity and Diversity: Local Cultures and Identities in China, (Hong Kong, Hong Kong University Press).

Sweeting, A. (1994) Hong Kong education within historical process, in: G. Postiglione \& Leung, Y.M. (Eds) Education and Society in Hong Kong: Toward One Country and Two Systems (Hong Kong, Hong Kong University Press).

Sweeting, A. \& Morris, P. (1993) Educational Reform in Post-war Hong Kong: Planning \& Crisis Intervention. International Journal of Education Development, 13(3), pp. 201-16.

Turner, M. (1995) 60’s/90’s dissolving the people, in: M. Turner \& I. Ngan (Eds) Hong Kong Sixties: Designing Identity (Hong Kong, Hong Kong Arts Centre).

Vines, S. (1998) Hong Kong: China’s New Colony. (London, Aurum Press). 
Table I Citizen Participation and its Educational Implications

\begin{tabular}{|c|c|c|c|c|c|}
\hline & $\begin{array}{l}\text { Participatory/ } \\
\text { Democratic }\end{array}$ & \begin{tabular}{|l} 
Conservative/ \\
Elitist
\end{tabular} & $\begin{array}{l}\text { Totalitarian/ } \\
\text { Manipulative }\end{array}$ & $\begin{array}{l}\text { Nationalist/ } \\
\text { Integrative }\end{array}$ & $\begin{array}{l}\text { World/ } \\
\text { Universalist }\end{array}$ \\
\hline $\begin{array}{l}\text { Assumptions } \\
\text { re individuals }\end{array}$ & $\begin{array}{l}\text { Commonsense } \\
\text { of the masses - } \\
\text { beneficial }\end{array}$ & $\begin{array}{l}\text { Only an elite } \\
\text { is wise and } \\
\text { altruistic }\end{array}$ & $\begin{array}{l}\text { Duty to support } \\
\text { ideology }\end{array}$ & $\begin{array}{l}\text { Personality } \\
\text { dependent on } \\
\text { national identity }\end{array}$ & $\begin{array}{l}\text { Human identity } \\
\text { more significant } \\
\text { than national }\end{array}$ \\
\hline \begin{tabular}{|l} 
Political \\
involvement
\end{tabular} & $\begin{array}{l}\text { Maximum use } \\
\text { of opportunities } \\
\text { for participation }\end{array}$ & $\begin{array}{l}\text { Minimal } \\
\text { participation - } \\
\text { to support } \\
\text { elite }\end{array}$ & $\begin{array}{l}\text { Enthusiastic } \\
\text { mass support of } \\
\text { leadership }\end{array}$ & $\begin{array}{l}\text { Support for } \\
\text { national cohesion } \\
\text { and greatness }\end{array}$ & $\begin{array}{l}\text { Duty to raise } \\
\text { consciousness } \\
\text { about the world }\end{array}$ \\
\hline $\begin{array}{l}\text { Purpose of } \\
\text { politics }\end{array}$ & $\begin{array}{l}\text { Maximise } \\
\text { individual } \\
\text { freedom and } \\
\text { equality }\end{array}$ & $\begin{array}{l}\text { Preservation } \\
\text { of traditional } \\
\text { values through } \\
\text { process of } \\
\text { change }\end{array}$ & $\begin{array}{l}\text { Achievement of } \\
\text { the 'ideal' } \\
\text { society }\end{array}$ & $\begin{array}{l}\text { National } \\
\text { integration and } \\
\text { differentiation }\end{array}$ & $\begin{array}{l}\text { Subordination of } \\
\text { national to world } \\
\text { interest }\end{array}$ \\
\hline \begin{tabular}{|l} 
Educational \\
Policies
\end{tabular} & $\begin{array}{l}\text { Development of } \\
\text { individual's } \\
\text { aptitudes but } \\
\text { social } \\
\text { homogenisation }\end{array}$ & $\begin{array}{l}\text { Distinction } \\
\text { between elite } \\
\text { and mass } \\
\text { education }\end{array}$ & $\begin{array}{l}\text { Politicisation of } \\
\text { whole school } \\
\text { system }\end{array}$ & $\begin{array}{l}\text { National rather } \\
\text { than sectional } \\
\text { provision }\end{array}$ & $\begin{array}{l}\text { Co-operation and } \\
\text { tolerance }\end{array}$ \\
\hline \begin{tabular}{|l} 
Political \\
education \\
policies
\end{tabular} & $\begin{array}{l}\text { Knowledge and } \\
\text { understanding of } \\
\text { the system, } \\
\text { participative } \\
\text { skills }\end{array}$ & $\begin{array}{l}\text { Deference } \\
\text { from the } \\
\text { masses, } \\
\text { loyalty from } \\
\text { all }\end{array}$ & $\begin{array}{l}\text { Indoctrination } \\
\text { and } \\
\text { regimentation }\end{array}$ & $\begin{array}{l}\text { National } \\
\text { consciousness and } \\
\text { patriotism }\end{array}$ & $\begin{array}{l}\text { Empathetic } \\
\text { understanding of } \\
\text { other people and } \\
\text { global problems }\end{array}$ \\
\hline $\begin{array}{l}\text { Participants in } \\
\text { the policy } \\
\text { making } \\
\text { process }\end{array}$ & \begin{tabular}{|l} 
Elected \\
members of \\
Government. \\
All groups with \\
an interest
\end{tabular} & $\begin{array}{l}\text { Members } \\
\text { selected from } \\
\text { society's elite }\end{array}$ & $\begin{array}{l}\text { The state/civil } \\
\text { service }\end{array}$ & $\begin{array}{l}\text { Those promoting } \\
\text { national interests/ } \\
\text { identity }\end{array}$ & $\begin{array}{l}\text { All stakeholders } \\
\text { in the process of } \\
\text { global } \\
\text { reconstruction }\end{array}$ \\
\hline
\end{tabular}

Source: Adapted from Heater, Derek Benjamin (1990) Citizenship: The Civic Ideal in World History, Politics and Education (London, Longman) pp.213 